Jurnal Konstruksi Hukum | ISSN: 2746-5055

Vol. 2, No. 1, Januari 2021 Hal. 154-159 | Tersedia online di https://www.ejournal.warmadewa.ac.id/index.php/jukonhum DOI: https://10.22225/jkh.2.1.2986.154-159

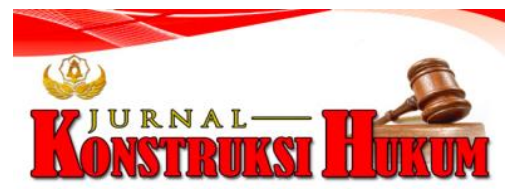

\title{
SANKSI PIDANA TERHADAP PELAKU TINDAK PIDANA INFORMASI DAN TRANSAKSI ELEKTRONIK
}

\author{
Komang Gede Dicki Saputra, I Made Sepud, Diah Gayatri Sudibya \\ Fakultas Hukum Universitas Warmadewa, Denpasar-Bali, Indonesia
}

\begin{abstract}
Abstrak
Internet merupakan salah satu media elektronik bidang informasi dan komunikasi yang mampu menghubungkan masyarakat di seluruh dunia, sehingga dunia terasa menjadi semakin sempit dan tanpa batas karena kemudahan dalam menjalin komunikasi. Indonesia saat ini mengalami masalah yang serius yaitu masyarakat sudah tidak taat kepada hukum, bahkan beberapa diantaranya buta tentang hukum bukan karena dia tidak paham hukum. Oleh sebab itu penting melakukan sosialisasi kepada masyarakat. Penelitian ini bertujuan untuk menjelaskan tindak pidana terhadap perlakuan yang menyiarkan informasi melalui sosial media sesrta solusi untuk menghindari perlakuan yang menimpang melalui sosial media. Penelitian ini didesain menggunakan penelitian hukum normatif yaitu mencari dan memilah informasi yang diperoleh diperpustakaan tanpa melenceng dari masalah yang dibahas dan hukum positif yang berlaku saat ini. Pendekatan yang digunakan yaitu peedekatan perundang-undangan. Sumber data penelitian yaitu data pimer dan skunder. Hasil penelitian menunjukkna bahwa Perbuatan seseorang yang dengan sengaja menjelekan nama seseorang baik itu dilakukan secara sengaja ataupun tidak dilakukan di depan umun atau di media sosial dapat dipidana penjara dan ganti rugi atas perbuatan yang dilakukannya yang kedua Pemerintah sebagai penjamin korban pencemaran nama baik tidak diam saja selain memberikan tanggungan kepada korban juga memberikan ganjaran setimpal berupa aturan yang berisi larangan bagi seseorang untuk merusak nama baik Pasal 37 Ayat (3) Undang-Undang ITE sebagai solusi bagi pemerintah untuk mengurangi tindak pidana pencemaran nama baik dan merupakan acuan hakim dalam memutus perkasa berkaitan pencemaran nama baik yang terjadi di media sosial.
\end{abstract}

Kata Kunci: Sanksi Pidana; Tindak Pidana; Elektronik

\begin{abstract}
The internet is one of the electronic media in the field of information and communication that is able to connect people around the world, so that the world feels increasingly narrow and borderless because of the ease in establishing communication. Indonesia is currently experiencing a serious problem, namely that the people are no longer obedient to the law, even some of them are blind about the law not because they do not understand the law. Therefore it is important to socialize to the community. This study aims to explain criminal acts against the treatment of broadcasting information through social media as well as a solution to avoiding unfair treatment through social media. This research is designed to use normative legal research, which is looking for and sorting information obtained in the library without deviating from the issues discussed and the current positive law. The approach used is the statutory approach. Sources of research data are primary and secondary data. The results of the research show that the actions of a person who deliberately defames someone's name, whether it is done intentionally or not in public or on social media, can be sentenced to prison and compensation for the actions he has committed which the two Governments as guarantor of defamation victims do not remain silent other than Providing dependents to the victim also provides compensation in kind in the form of rules that prohibit someone from damaging the good name of Article 37 Paragraph (3) of the ITE Law as a solution for the government to reduce criminal acts of defamation and is a reference for judges in deciding matters related to defamation that's happening on social media.
\end{abstract}

Keywords: Criminal Sanctions; Criminal act; Electronic

\section{PENDAHULUAN}

Indonesia saat ini mengalami masalah yang serius yaitu masyarakat cuek dan tidak mematuhi hukukm, bahkan beberapa diantaranya buta tentang hukum bukan karena ia tidak paham hukum. Oleh sebab itu penting melakukan sosialisasi agar masyarakat Indonesia menyadari akibat dari hukum itu sendiri. Peraturan hukum positif di Indonesia merupakan hukum yang bersifat mutlak dan harus diketahui setiap orang tanpa kecuali. Sebagai warga yang baik sudah sepatutnya sadar hukum bukan hanya cukup mengetahui saja tetapi mengerti akibat hukum dari pelanggaran hukum yang dilakukan. Siapapun dan kapanpun seseorang bisa saja melakukan pelanggaran hukum baik sengaja 
maupun tidak disengaja yang dapat merugikan individu atau kelompok masyarakat (Gerry Kenjiro Tanos, 2016). Dengan demikian maka fungsi hukum sebagai alat pemberi sanksi bagi para pelaku tindak pidana juga sebagai perlindungan bagi seseorang yang menjadi korban tindak pidana. Hukum positif di Indonesia diberlakukan berdasarkan ideologi-ideologi pancasila dan tidak melenceng dari hak asasi manusia (Soesilo Waluyo, 2009). Mempelajari hukum dan penerapan sanksi bagi seseorang yang melanggar hukum, Peraturan-peraturan yang dibuat bukan hanya peringatan biasa, tetapi wajib untuk ditegakkan dan dilaksanakan oleh setiap warga negara dengan tidak ada pengecualian

Era globalisasi membawa perubahan pada kemajuan teknologi informasi dan komunikasi menuju modernisasi bahkan membuat kehidupan manusia menjdai ketergantungan terhadap teknologi (Hendro Setyo Wahyudi, 2014). Manusia dihadapkan pada kecanggihan beragam teknologi yang menggiurkan dan dirasa semakin penting dalam prosesnya sebagai akibat dari tuntutan aktifitas kehidupan. Kecanggihan perkembangan teknologi komputer khususnya dalam sistim telekomunikasi melahirkan istilah baru yang disebut dengan internet. Internet merupakan salah satu media elektronik dalam hal informasi dan komunikasi yang mampu menghubungkan masyarakat di seluruh dunia, sehingga dunia terasa menjadi semakin sempit dan tanpa batas karena kemudahan dalam menjalin komunikasi. Seiring dengan perkembangan zaman pada saat ini, maka berkembang pula jenis-jenis kejahatan yang baru (Erdianto \& Erdiansyah, 2016).

Dalam perkembangannya, komputer yang mulanya hanya digunakan untuk menyelesaikan tugas, pekerjaan dan lain sebagainya telah memunculkan hal baru terutama ketika telah dikoneksikan dengan jaringan internet. Era globalisasi saat ini telah memajukan sistem internet dan komunikasi, banyak masyarakat yang terbantu dengan teknologi canggih seperti smartphone mempermudah memperoleh infomasi serta bisa meningkatkan taraf hidup masyarakat dengan berniaga melalui media online dan dalam hal pembangunan dari berbagai bidang kehidupan. Kebutuhan manusia yang semakin meningkat seiring dengan perjalanan arus globalisasi. Globalisasi yang melahirkan teknologi informasi dan komunikasi berbasis internet telah membentuk pola hidup manusia dengan budaya baru. Dengan adanya internet, manusia tidak lagi khawatir dengan batas wilayah, ruang, dan waktu yang menghalangi proses informasi dan komunikasi karena telah menemukan suatu yang lebih efektif dan efisien.

Pemanfaatan internet ini terbukti dengan salah satu munculnya media sosial dengan menggunakan sarana internet dalam menjalankannya. Internet memiliki fitur-fitur canggih jejaring sosial diantaranya adalah facebook, twitter, line, dan lain sebagainya. Bahkan saat ini internet tidak hanya bisa di akses melalui komputer, tetapi juga melalui gadget (telpon pintar) dan handphone (telepon genggam). Jejaring sosial dunia maya memiliki berbagai manfaat sebagai sarana chatting, hiburan, kuis, permainan, publikasi opini, serta informasi terbaru yg aktual. Namun seringkali para pengguna jejaring sosial menyalahgunakan manfaatnya dengan melakukan hal-hal yang menyalahi norma dan terkadang memperkosa hak orang lain.

Seiring dengan perkembangan internet dengan berbagai fasilitas kemudahan yang diberikannya sebagai sarana pertukaran informasi dan dalam berkomunikasi salah satunya melalui fitur jaringan sosial, dalam pemanfaatannya mendatangkan berbagai masalah baru. Semakin banyaknya pengguna internet semakin banyak pula permasalahan yang ditimbulkan, diantaranya adalah munculnya kejahatan baru di dunia maya yang disebut cyber crime. Aplikasi tersebut berfungsi sebagai pemantau penggunaan internet, memblok akses masuk ke situs-situs yang bersifat pornografi, seks dan sara, serta situs lain yang bersifat merusak moral serta pola pokir generasi penerus bangsa selain itu fungsi cyber crime memantau jika terjadi penipuan melalui internet dan perjudian secara online (Maskun, 2011). Manusia memiliki hak asasi manusia, antara lain kebebasan untuk mengemukakan pendapat. Media jejaring sosial merupakan salah satu sarana perantara komunikasi yang digunakan untuk mengeluarkan pendapat. Namun dalam praktiknya telah terjadi kesalah pahaman mengenai pemanfaatan jejaring sosial, sehingga kebebasan berpendapat tersebut seringkali disalahgunakan oleh berbagai kalangan. Kebebasan tersebut kemudian memancing permasalahan baru yang membuat seseorang namanya menjadi jelek dimata masyarakat dan penghinaan. Tindakan seseorang yang merusak nama baik tidak dapat dibenarkan dan tidak dapat diukur secara pasti karena masih harus dikaji lebih detail mengenai faktor-faktor pendukungnya. Faktor-faktor pendukung tersebut bisa terjadi karena sifat iri yang menjadi kesengajaan demi menghancurkan citra seseorang, dilakukan tanpa ada persetujuan dan masih banyak lagi (Awan, 2012). Setiap orang memiliki kewajiban saling menghargai, toleransi satu sama lain demi 
Terciptanya keadaan yang harmonis antara individu dengan individu atau individu dengan kelompok. Seseorang memiliki hak untuk diperlakukan dan dihormati di dalam kehidupan bermasyarakat.

Penghormatan nama baik merupakan penilaian sudut moral yang perlu mendapatkan perlindungan karena hal tersebut seringkali mendapatkan penyerangan yang diukur menurut lingkungan masyarakat dimana perbuatan tersebut dilakukan. Penelitian ini bertujuan untuk menjelaskan tindak pidana terhadap perlakuan yang menyiarkan informasi melalui sosial media dan menjelaskan solusi untuk menghindari perlakuan yang menimpang melalui sosial media.

Penelitian sebelumnya mengungkapkan bahwa Perbuatan terdakwa menimbulkan kerugian bagi orang lain dan dapat menghilangkan kepercayaan orang kepada lembaga perbankan serta meresahkan masyarakat (Rivan, 2016). Selanjutnay Tanos, (2016) Pelaku penghinaan melalui media sosial akan dikenakan sanksi sesuai peraturan yang berlaku. Sanksi dari tindak pidana penghinaan diatur dalam Pasal 45 ayat (1) UU ITE, dengan pidana penjara paling lama 6 (enam) tahun dan/atau denda paling banyak Rp1.000.000.000,00 (satu miliar rupiah). Tindak pidana penghinaan melalui media sosial merupakan delik yang diatur di dalam Pasal 27 ayat (3) Undang-Undang Nomor 11 Tahun 2008 tentang Informasi dan Transaksi Elektronik (ITE). Tindak pidana penghinaan melalui media sosial merupakan delik aduan sehingga harus adanya laporan atau aduan dari masyarakat atau individu yang merasa dirugikan atas pernyataan dari orang lain (Bahar et al., 2015).

\section{METODE PENELITIAN}

Penelitian ini didesain mengunakan penelitian hukum normatif yaitu berpatokan pada peraturan pemerintah dan Informasi yang didapat secara konseptual berkaitan dengan masalah yang diteliti. Penelitian hukum normatif adalah mencari dan memilah informasi yang diperoleh diperpustakaan tanpa melenceng dari masalah yang dibahas dan hukum positif yang berlaku saat ini (Waluyo, 2002). Pendekatan yang digunakan yaitu Pendekatan perundangan-undangan adalah melakukan suatu penelitian dengan berpatokan pada undang-undang. Pendekatan kasus dilakuka guna melihat, mencatat dan memahami permasalahan yang sedang diteliti dengan tidak keluar dari zona hukum positif. Data yang digunakan bersumber dari data hukum primer dan sekunder.

\section{HASIL DAN PEMBAHASAN}

\section{Tindak Pidana Terhadap Pelaku Fitnah Melalui Sosial Media}

Penghinaan terhadap seseorang dengan unsur kesengajaan demi membuat malu seseorang yang diakukan di dunia maya atau tempat umum merupakan definisi pencemaran nama baik. Dari ketentuan yang ada dalam KUHP, ada enam macam penghinaan diantaranya Menista/smaad (pasal 310 KUHP), Memfitnah/laster (Pasal 311 KUHP ), Penghinaan Ringan/envoundige belediging (Pasal 315), Mengadu Dengan Memfitnah/lasterlijke (Pasal 317), menyuruh dengan memfitnah/lasterlijke verdachtmaking (Pasal 318). Perbuatan seseorang yang melakukan penghinaan terhadap seseorang tidak bisa dibenarkan dan merupakan suatu pelanggaran hukum. Sebagai korban dari pencemaran nama baik dapat mengadukan tuduhan kepada pihak terkait agar pelaku penghinaan dapat diberi hukuman atas perbuatannya apa lagi perbuatan tersebut terdapat sanksi yang melihat sendiri perbuatan yang dilakukan maka hukuman menjadi pasti. Dalam UU ITE sudah sangat jelas dan tegas di atur mengenai penerapan sanksi terhadap pelaku pencemaran nama baik.

Pidana penjara dan denda dipastikan menjadi ganjaran bagi seseorang yang sengaja menuduh hal yang tidak benar dengan tujuan menghina dan menjatuhkan harga diri seseorang. Perbuatan tersebut dapat dikategorikan perbuatan pencemaran nama baik. Undang-Undang ITE mengatur tentang perbuatan seseorang yang mencemarkan nama baik yang berlaku pada setiap warga baik berada di Indonesia maupun diluar daerah. Sanksi bagi seseorang yang melakukan pencemaran nama baik ada pada pasal 23 ayat (3) di denda maksimal 1 miliyar rupiah. Denda yang sangat besar bagi orang yang dengan semaunya melecehkan nama seseorang demi keuntungan pribadi semata. Setiap manusia yang ada di dunia mempunyai beragam sifat yang mana ada hidup dengan biasabiasa saja tanpa mengurusi hidup orang lain dan banyak yang melakukan perbuatan sebaliknya namun tidak mengetahui hukuman atas perbuatan yang dilakukannya.

Siapapun yang melakukan perbuatan baik itu benar atau salah dialah yang akan mendapatkan hasil daripada perbuatannya, tinggal sekarang bagaimana mengambil sikap bila melakukan tindak 
pidana maka siap dengan sanksi dan hukumann (Notodisoerjo, 1993). Pertanggung jawaban seseorang sangat diperlukan dari apa yang sudah diperbuat. Pemerintah bertugas memberikan tanggungan dari korban pencemaran nama baik dengan melindungi seseorang dengan hukum yang membuat kedepannya tidak ada lagi kasus pencemaran nama baik. Sudah seharusnya bila ada korban dari pencemaran nama baik, maka pemerintahlah yang harusnya memberikan perlindungan bahkan hukum Internasional memberlakukan hal yang sama.

Perkembangan teknologi elektronik komputer mengharuskan adanya norma yang mengatur tentang perkembangan teknolgi di Indonesia. Tatanan hukum yang baru akan menciptakan tatanan sosial yang baru supaya keamanan dan kenyamanan dalam menggunakan manfaat teknologi informasi dan komunikasi tetap efektif. Di samping itu, Undang-Undang ITE mengatur ancaman hukuman setiap tindak kejahatan yang dilakukan melalui media elektronik komputer yang berbasis internet. Peraturan tersebut dimaksudkan untuk memberikan kepastian hukum bagi masyarakat pada umumnya, dengan mengesahkan barang bukti yang sah di pengadilan berupa tanda tangan elektronik dan dokumen elektronik. Kehadiran undang-undang tersebut dapat memberikan pencegahan maupun penanganan terkait dengan setiap setiap tindak kejahatan yang dilakukan melalui media elektronik yang dirasa masih sulit untuk dipecahkan, terutama dalam proses pembuktian dalam rangka penegakan hukum. Keterbatasan aturan hukum telematika dan minimnya kualitas sumber daya manusia menjadi alasan jaksa penuntut umum dan hakim dalam mengambil keputusan menjadi rancu.

\section{Peranan Pemerintah dalam Mengatasi Perlakuan yang Menyimpang Melalui Sosial Media.}

Pemerintah juga berperan penting dalam merumuskan kerangka hukum yang akomodatif terhadap masalah-masalah yang dihadapi. Pihak yang dapat dipertanggung jawabkan tidak hanya orang, melainkan juga badan hukum karena keduanya bertindak sebagai subjek hukum. Hukum sebagai fungsinya panutan masyarakat mengajarkan bagaimana seseorang harus bertindak dan bertingkah laku demi terciptanya keharmonisan dalam bermasyarakat. Dari penjelasan di atas peneliti merangkum fungsi hukum ditinjau dari ranah pidana dan teknologi informasi komunikasi yaitu :

a. Memberi pedoman anggota masyarakat dalam bertingkah laku. Melalui aturan yang berkaitan dengan teknologi akan diketahui tentang langkah-langkah yang harus ditempuh oleh masyarakat agar tidak menjadi pelaku atau menjadi korban.

b. Menjaga keutuhan masyarakat. Jika dalam masyarakat ternyata terjadi cyber crime, maka negara melalui lembaga penegak hukum dapat menjatuhkan pidana kepada pelaku dan dapat memberikan perlindungan kepada korban. Upaya menjatuhkan sanksi kepada pelaku, melindungi kepentingan hukum pelaku dan korban, serta melindungi masyarakat sebenarnya adalah upaya mengutuhkan masyarakat kembali yang tatanannya agak terpecah karena adanya tindak pidana.

c. Melakukan pengendalian sosial. Melalui hukum pidana dibidang teknologi informasi, anggota masyarakat dapat mengendalikan kehidupan agar tidak melakukan tindak pidana segala tingkah lakunya akan terkendali dalam rangka mencapai tujuan masyarakat.

Peraturan perundang-undangan sebenarnya ditunjukkan untuk dapat digunakan sebagaimana mestinya sesuai dengan fungsi yang sebenarnya, salah satunya adalah untuk melindungi reputasi masyarakat atau subjek hukum, baik itu secara perorangan maupun berbentuk badan. Namun dalam praktiknya yang terlihat malah sebaliknya, undang-undang justru digunakan sebagai gembok untuk mengunci dan membatasi hak kebebasan warga negara untuk mengeluarkan pendapat, mengkritik, dan mengungkap kebenaran. Ancaman pidana yang berat dapat menjadi batu sandungan bagi setiap warga negara dalam berekspresi. Yurisprudensi merupakan salah satu sumber hukum yang terdiri dari kumpulan keputusan hakim atau pengadilan yang memiliki kekuatan huku tetap, dan memiliki peranan penting dalam mengisi kekosongan hukum (judge made law) dalam memutus suatu perkara. Yurisprudensi dijadikan dasar untuk menghakimi perbuatan seseorang apabila perbuatan yang dimaksud tidak secara jelas diatur dalam undang-undang, putusan harus memiliki kekuatan hukum teap, memenuhi rasa keadilan, pernah dijadikan sebagai dasar untuk memutuskan perkara sejenismdan Mahkamah Agung membenarkan putusan tersebut.

Dalam menyelesaikan kasus pencemaran nama baik terdapat hal-hal yang harus dipertimbangkan secara matang. Diperlukan pelatihan khusus terhadap aparat hukum dan memfasilitasi dalam pengumpulan bukti, sistem hukum yang digunakan harus sesuai dan relevan terhadap permasalahan, dalam proses penyidikan dan pembuktian pakar IT supaya dapat mengetahui 
keaslian dokumen atau data elektronik dan mendesain sistem keamanan media informasi dan transaksi elektronik untuk mencegah penyalahgunaan fungsi komputer beserta jaringannya. Terhadap tindak pidana pencemaran nama baik atau penghinaan melalui jejaring sosial dapat dilakukan penuntutan oleh penuntut umum. Untuk dapat melakukan penuntutan, kelengkapan berkas perkara harus mengandung bukti yang menguatkan pembenaran telah adanya tindak pidana tersebut yang kemudian ditindaklanjuti dengan pembuatan dakwaan. Penahanan dapat dilakukan apabila syarat subjektif, objektif, dan syarat kelengkapan formal telah dipenuhi. Syarat subjektif yang melekat pada diri pelaku tindak pidana, sedangkan unsur objektif berkaitan dengan keadaan dimana tindakan kejahatan tersebut harus dilakukan oleh pelaku.

Dalam proses peradilan, yang menjadi kendala adalah sulitnya mengumpulkan barang bukti dan pengajuan barang bukti di pengadilan. Pelaku memiliki banyak modus perandi dalam melakukan penyalahgunakan komputer, sehingga menyebabkan kesulitan dalam hal pemenuhan syarat materiil pengajuan gugatan. Apabila tidak memenuhi ketentuan sebagaimana dimaksud, maka dikatakan batal demi hukum. Tujuan dari pemidanaan antara lain adalah untuk memberikan perlindungan kepada masyarakat, menjaga solidaritas dalam masyarakat, untuk mencegah damn menanggulangi pelaku supaya menjadi orang yang baik dan tidak terjadi lagi perbuatan kejahatan yang sama dan untuk menyelesaikan konflik yang terjadi sehingga tercipta rasa damai dalam masyarakat.

Pemerintah bergerak cepat dalam usahanya mengurahi perbuatan tidak terpuji yaitu melakukan pencemaran nama baik dengan modus setiap tersangkanya berbeda beda dengan menerapkan aturan tentang larangan melakukan perncemaran nama baik dengan tujuan agar seseorang dapat berfikir dulu sebelum bertindak, bagi tersangka akan dikenakan sanksi dan denda sesuai perbuatan mereka. Diperlukan pendekatan secara rasional untuk dapat menentukan setiap kebijakan hukum pidana supaya konsepsinya dapat ditetapkan secara sadar dan matang dalam menggunakan sanksi pidana untuk memberikan perlindungan terhadap kepentingan sosial masyarakatyang memang perlu untuk dilindungi. Sanksi pidana harus disesuaikan dengan kebutuhan yang memiliki manfaat bagi masyarakat dan nilai - nilai perwujudannya. Sanksi pidana juga harus mampu menumbuhkan kesadaran diri pelaku pencemaran nama baik dan penghinaan sehingga tercipta efek jera.

\section{SIMPULAN DAN SARAN}

\section{Simpulan}

Dari analisis data diketahui bahwa perbuatan seseorang yang sengaja menjelekan nama seseorang baik itu dilakukan secara sengaja ataupun tidak dilakukan di depan umun atau di media sosial dapat dipidana penjara dan ganti rugi atas perbuatan yang dilakukannya, yang kedua pemerintah sebagai penjamin korban pencemaran nama baik tidak diam saja selain memberikan tanggungan kepada korban juga memberikan ganjaran setimpal berupa aturan yang berisi larangan bagi seseorang untuk merusak nama baik, pasal 37 Ayat (3) Undang-Undang ITE sebagai selusi bagi pemerintah untuk mengurangi tindak pidana pencemaran nama baik dan merupakan acuan hakim dalam memutus perkasa berkaitan pencemaran nama baik yang terjadi di media sosial.

\section{Saran}

Ada beberapa yang menjadi saran terkait penelitian ini yaitu bagi aparat penegak hukum, Majelis Hakim, Jaksa, dan penegak hukum lainnya sebagai tiang yang menjaga ketentraman dan kemakmuran masyarkat agar lebih konsisten dan lebih tegas dalam menindak para pelaku tindak pidana khususnya dalam hal ini pelaku tindak pidana pencemaran nama baik melalaui sosial media, yang kedua bagi masyarakat Indonesia agar senantiasa menjaga kehormatan diri sendiri dan orang lain, meningkatkan nilai sopan santun demi terciptanya kesejahteraan di lingkungan masyarakat. Sebagai pengguna teknologi diharapkan gunakanlah teknologi sesuai dengan fungsinya dan jangan keluar zona dengan melanggar aturan-aturan yang berlaku di Indonesia.

\section{DAFTAR PUSTAKA}

Bahar, S. A., Supanto, \& Fitriono, R. A. (2015). Penerapan Sanksi Pidana dalam Penanggulangan Tindak Pidana Penghinaan Melalui Media Sosial. Jurnal Recidive, 4(1), 110-119.

Erdianto, \& Erdiansyah. (2016). Penerapan Sanksi Pidana dalam Penanggulangan Tindak Pidana Penghinaan 
Melalui Media Sosial Tinjauan Yuridis Tindak Pencemaran Nama Baik Melalui Media Sosial Berdasarkan Pasal 27 Ayat (3) Undang-Undang Nomor 11 Tahun 2008 Tentang Informasi dan Transaksi El. JOM Fakultas Hukum, 3(1), 1-15.

Gerry Kenjiro Tanos. (2016). Penerapan Sanksi Pidana terhadap Pelaku Penghinaan Melalui Media Sosial Menurut Undang-Undang Nomor 11 Tahun 2008 Tentang Informasi dan Transaksi Elektronik. Jurnal Lex et Societatis, 4(1), 165-183.

Hendro Setyo Wahyudi, M. P. S. (2014). Teknologi dan Kehidupan Masyarakat. Jurnal Analisa Sosiologi, 3(1), $13-24$.

Maskun. (2011). Kejahatan Siber Cyber Crime,. Media Pustaka.

Notodisoerjo, S. (1993). Hukumi Notariat di Indonesia. Raja Grafindo Persada.

Rivan, S. S. (2016). Penerapan Penjatuhan Sanksi Pidana Terhadap Pelaku Pencurian Dokumen Elektronik Milik Orang Lain di Kota Makassar. Jurbal Hukum, 1(1), 80-103.

Soesilo Waluyo. (2009). Penyelesaian Perkara Pidana Berdasarkan KUHAP Sistem dan Prosedur. alumni.

Tanos, G. K. (2016). Penerapan Sanksi Pidana Terhadap Pelaku Penghinaan Melalui Media Sosial Menurut Undang-Undang Nomor 11 Tahun 2008 Tentang Informasi Dan Transaksi Elektronik. Lex Et Societatis, 4(1), 165-173.

Waluyo, B. (2002). Penelitian Hukum Praktek. Sinar Grafika. 